\title{
Impact of Spray Drying Parameters on Lactose-Free Milk Powder Properties and Composition
}

\author{
Larissa Rodrigues, Gustavo Paiva, Hugo M Lisboa, Matheus Pasquali, Rennan Gusmão, \\ Maria Elita Duarte, Mario Eduardo Cavalcanti-Mata, Thaisa Abrantes \\ Unidade Academica Engenharia de Alimentos, Universidade Federal Campina Grande, Brazil
}

Received: Nov. 24, 2019

Accepted: Jan. 10, 2020

Published: Jan. 13, 2020

doi:10.5296/jas.v8i3.15886

URL: https://doi.org/10.5296/jas.v8i3.15886

\begin{abstract}
Lactose-free milk powders are an interesting topic, as the industry still struggles with the enhanced stickiness of the material. To better understand this topic, an industrial scale spray-dryer was used to assess the influence of process parameters on the powder properties of lactose-free milk. A simple design of experiments was conducted varying the inlet temperature in combination with the atomization flow rate. The intention was to set different driving forces for drying in combination with the different surfaces are for mass transport. Yield is typically the process bottleneck, but from results, high inlet temperature combined with small droplet size resulted in a $50.73 \%$ yield. Powder's moisture contents were between $0.53 \%$ and $5 \%$, and water activity between 0.21 and 0.43 , being all values within a safety threshold for storage. From bulk and tap density results, all powders revealed to be cohesive with the Hausner ratio above 1.5. Color measurements revealed off white samples, with a tendency to become brown when higher inlet temperatures are used, possibly due to Maillard reactions. Powder particle size ranged from 5.6 to $13.5 \mathrm{~mm}$ and revealed extensive agglomeration, possibly due to some protein denaturation at the particle surface. Inlet temperature revealed to be the most influential parameter on all properties.
\end{abstract}

Keywords: drying, powder, milk, hydrolyzed milk, lactose-free

\section{Introduction}

Lactose maldigestion in human adults can result in gastrointestinal discomfort after consuming lactose-containing products, a condition known as lactose intolerance, which is why many people avoid dairy products Hertzler et al. (2017). The frequency of lactose intolerance varies considerably between different ethnic groups and populations, with the lowest rates in North European, North American and Australasian people (5-18\%) and the highest ones in South Americans, Africans and Asians with approximately 50\% of the population affected and almost $90 \%$ in some Far East countries (Monti et al., 2017). The 
important nutritional value of dairy products has, therefore, led to the production of low-lactose or lactose-free products (Geiger et al., 2016). Lactose-free and low-lactose products such as yogurt, UHT milk, and beverages, as well as cheese, are well-established on the market in many countries (Milkovska-Stamenova \& Hoffmann, 2017; Moreira et al., 2017), but the production of lactose-free milk powder remains an under-studied field. Lactose-free milk powder is also inserted within these new trends but still faces significant technological challenges. One of the challenges arises from the fact that hydrolyzed lactose becomes extremely rich in low molecular weight molecules, such as glucose and galactose (Jansson et al., 2014). These molecules, combined with small amounts of , render a product with a glass transition temperature lower than the typical drying temperatures (Ahmad \& Nguyen, 2017). This phenomena results in milk sugars above the glassy state yielding higher molecular mobility and higher hygroscopicity, both increasing the Maillard reaction rate that affects sensory properties and shelf-life (Cheng et al., 2017). Due to high throughput and continuous operation, spray drying is considered the most cost-effective drying process. The principle of spray drying is to remove the water from the milk concentrate as fast and at as low temperature as possible to minimize heat damage to the milk solids (Nascimento et al., 2019). This unit operation is widely used in the food industry and is applied mainly for food preservation (Shishir \& Chen, 2017). When considering spray-drying, an undesirable but inevitable technological problem arises when drying above the glass transition. Due to lower viscosity, particles being formed tend to stick to the drying chamber walls, resulting in extensive clogging on drying chambers, including unwanted adhesion of agglomerated particles to the equipment, caking, and darkening (Ozmen \& Langrish, 2002). These issues lead to low production yields, operational problems, and difficulty in powder handling (Munir et al., 2017). Moisture sorption behavior and glass transition temperature $\left(T_{\mathrm{g}}\right)$ are two important properties of spray-dried milk powders that largely determine the processing conditions, product quality (such as stickiness, hygroscopicity, and caking behavior) and stability (storability and handling) of the final product (Roos \& Drusch, 2015). The relationships among product composition, degree of crystallinity, spray-drying settings, and powder properties play a key role in the industrial production of foods and have been widely researched for many foods materials. Although some work has been developed on the spray-drying of lactose-free milk, the influence of drying conditions has not yet been assessed. (Aguilar \& Ziegler, 1994), studied the effect of lactose content on spray dried milk powder and used inlet/outlet temperatures of $160 / 80^{\circ} \mathrm{C}$, while recently (Torres et al., 2017) and co-workers used $175 / 85^{\circ} \mathrm{C}$. Both works used lab-scale equipment. (Shrestha et al., 2007) used only one drying condition with inlet/outlet temperatures of $130^{\circ} \mathrm{C} / 65^{\circ} \mathrm{C}$ with $3 \mathrm{~L} / \mathrm{h}$ capacity, which is a pilot-scale equipment. (Fialho et al., 2017) studied the thermodynamics of the spray drying process of lactose-free milk on laboratory scale equipment, suggesting an optimum inlet temperature of $145 \mathrm{~kg} / \mathrm{h}$ and a product flow rate of $1 \mathrm{~kg} / \mathrm{h}$. The main focus of most works was the glassy-to-rubbery transition, moisture sorption behavior, and storage conditions. An understanding of spray drying variables on lactose-free powder milk properties can give some insight into the technological challenges of the process as well. An industrial-scale spray dryer was used during the present work. The importance of the scale is related to the residence time within the drying chamber because time/temperature history can 
affect powder properties and product quality. Therefore, the objective of the present work was to investigate the effects of various spray drying conditions on the properties of spray-dried lactose-free milk powders using an industrial scale spray dryer.

\section{Materials and Methods}

\subsection{Materials}

Commercial whole milk from the Brazilian dairy producer Cariri was bought at a local supermarket. Lactase enzyme (Kluyveromyces lactis) was provided by Prozyn ${ }^{\circledR}$ (São Paulo, Brazil).

\subsection{Whole Milk Hydrolysis}

In order to hydrolyze the whole milk, $0.08 \% \mathrm{w} / \mathrm{w}$ of Lactase enzyme (Kluyveromyces lactis) was added, and samples were incubated at $40{ }^{\circ} \mathrm{C} \pm 1{ }^{\circ} \mathrm{C}$. The average hydrolysis time was two hours, and \% hydrolysis was followed by cryoscopy until $99 \%$ of lactose hydrolysis was reached. The degree of hydrolysis was monitored by measuring the freezing point depression in each sample every 15 minutes using an RTI MK540 Flex II Cryoscope (São Paulo, Brazil), and then calculations were performed using equation 1 . Determination of $\beta$-galactosidase enzymatic parameters such as $\mathrm{V}_{\max }$ and $\mathrm{K}_{\mathrm{m}}$ were estimated through the Lineweaver-Burk plot (Lineweaver \& Burk, 1934). The enzyme was thermally inactivated by heating the milk to $95{ }^{\circ} \mathrm{C}$ for $60 \mathrm{~s}$. Similar approaches were used elsewhere(Júnior et al., 2016; Torres et al., 2017).

$$
\% \text { Hydrolysis }=350.877 \times(\text { final cryoscopy }- \text { initial cryoscopy })
$$

\subsection{Spray Drying}

Immediately after preparation, the hydrolyzed whole milk was spray-dried using a Labmaq SD10 spray dryer, equipped with a two-fluid nozzle, using atmospheric air as drying gas in open cycle mode (no air-recirculation) and as atomization gas. A design of experiments composed by a $2^{2}+1$ factorial was used, where atomization gas flow rate $\left(\mathrm{F}_{\text {atom }}\right)$ varied between 2 to $4 \mathrm{~kg} / \mathrm{h}$ and drying gas inlet temperature $\left(\mathrm{T}_{\text {in }}\right)$ varied between 110 and $150^{\circ} \mathrm{C}$, with a final center point of $3 \mathrm{~kg} / \mathrm{h}$ of $\mathrm{F}_{\text {atom }}$ and $130{ }^{\circ} \mathrm{C}$ of $\mathrm{T}_{\mathrm{in}}$. Other conditions were kept constant: drying gas flow rate $\left(\mathrm{F}_{\text {drying }}\right)$ was $288 \mathrm{~kg} / \mathrm{h}$, and the product flow rate $\left(\mathrm{F}_{\text {feed }}\right)$ was $2 \mathrm{~kg} / \mathrm{h}$. Each experimental point was performed two times.

\subsection{Moisture Content}

Powders moisture contents were determined gravimetrically by drying in an oven at $105^{\circ} \mathrm{C}$ until weight reached a constant value(A.O.A.C, 1990).

\subsection{Water Activity}

Water activity was determined using an Aqualab dew-point hygrometer, Decagon Devices, Inc, Pullman, Washington, USA. 


\subsection{Hygroscopicity}

Hygroscopicity was measured according to the method proposed by (Tonon et al., 2008), where $1 \mathrm{~g}$ of each powder sample was placed inside a closed vessel at $25^{\circ} \mathrm{C}$ with $\mathrm{NaCl}$ saturated solution for an approximate relative humidity of $75 \%$ (Tonon et al., 2008). After seven days, samples were removed and weighed. The difference was expressed as $\mathrm{g}$ $\mathrm{H}_{2} \mathrm{O} / 100 \mathrm{~g}$ of dry powder.

\subsection{Bulk Density, Tap Density and Hausner Index}

Bulk density was determined by pouring $3 \mathrm{~g}$ of powder samples into an empty $10 \mathrm{~mL}$ graduated measurement cylinder. The volume was registered, and the ratio of mass with occupied volume in cylinder gives the bulk density. Tap density was determined similarly, but the powder samples where tapped 100 times until the new volume was registered. Hausner Ratio is a number correlated with the powder flowability and can be given by Equation 2 .

$$
\text { Hausner Ratio }=\text { Tap Density/Bulk Density }
$$

\subsection{Color}

Color measurements were performed using a MiniScan XE Plus in the powder function, COLOR PLOT D65 / $10^{\circ}$. The values of $\mathrm{L}^{*}, \mathrm{a}^{*}$, and $\mathrm{b} *$ were determined for each sample.

\subsection{Scanning Electron Microscopy (SEM) and Particle Size Distribution}

Particle morphology was evaluated by scanning electron microscopy (SEM) with a TESCAN VEGAN 3, operating at an accelerating voltage at 5kVand with magnifications ranging from $250 x$ to $1000 x$. SEM images were analyzed in triplicate using image $\mathbf{J}$ for particle size distribution determination.

\section{$2.10 \mathrm{pH}$ and Acidity}

$\mathrm{pH}$ and acidity were determined using $10 \mathrm{~g}$ of each sample homogenized with $90 \mathrm{~mL}$ of distilled water. The $\mathrm{pH}$ was measured directly from the resulting solution $\mathrm{pH}$ using a potentiometer model 0400 (Quimis, São Paulo, Brazil), previously calibrated. Then, the suspension was titrated with $0.1 \mathrm{~N} \mathrm{NaOH}$ solution until $\mathrm{pH} 8.5$ was reached.

\subsection{Data Analysis}

The results from all characterizations were modeled upon the independent variables imposed in our experimental design. For that purpose, results were fitted into polynomial equations (eq.3), and the regression coefficients were determined. Then the obtained model was verified using ANOVA for lack of fit. All statistical calculations and contour plots were carried out using STATISTICA 12.0 Software.

$$
y=\beta 0+\beta 1 \times T_{\text {in }}+\beta 2 \times F_{\text {atom }}+\beta 3 \times T_{\text {in }} \times F_{\text {atom }}
$$




\section{Macrothink}

\section{Results and Discussion}

\subsection{Milk Hydrolysis}

Lactose-free milk was produced by enzymatic hydrolysis to study the spray drying process and the effects of drying conditions on lactose-free milk powder properties. The lactose hydrolysis curve is presented in Figure 1.

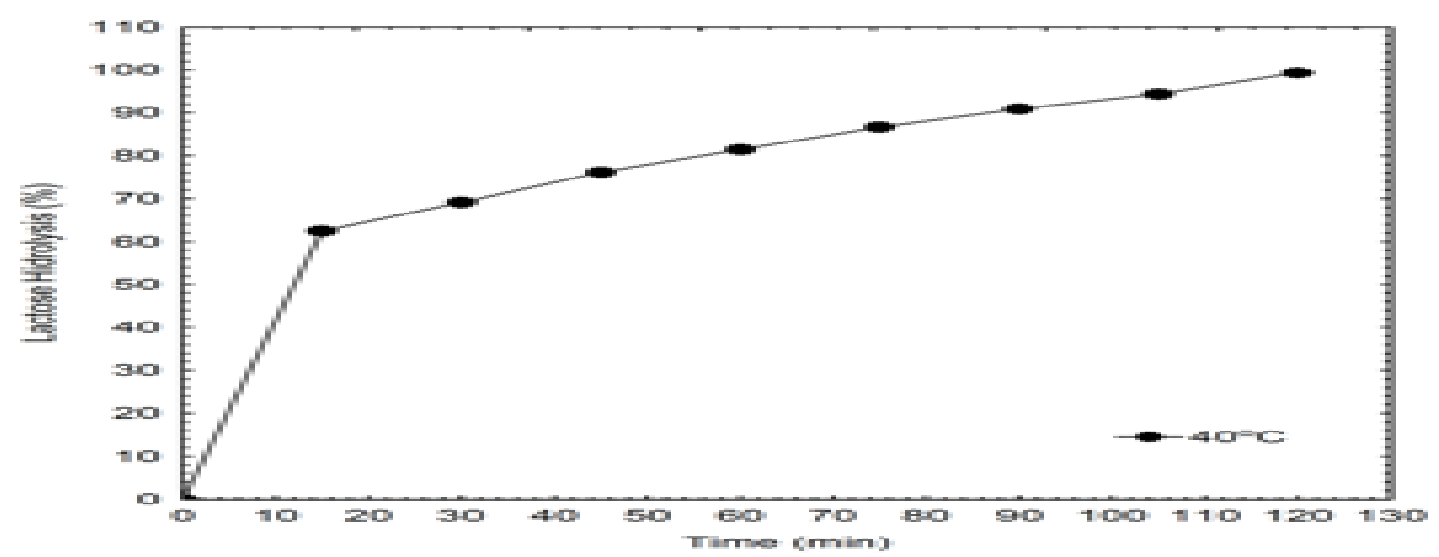

Figure 1. Hydrolysis curve of lactose on whole milk using free Prozyn Lactase enzyme under $40^{\circ} \mathrm{C}$ and $\mathrm{pH}=6.9$

The detection and quantification of hydrolysis in milk can be performed by chromatographic methods (Morlock et al., 2014), enzymatic (McCleary \& Charnock, 2010) and by cryoscopy (Nijpels et al., 1980). However, the cryoscopy method is the most used. Torres et al. (2017) evaluated the effects of five different levels $(0,25,50,75$, and 99\%) of enzymatic lactose hydrolysis $(0.2 \% \mathrm{w} / \mathrm{w}$ of Lactomax Super enzyme by Prozyn) during the production and storage of milk powder. The degree of hydrolysis was monitored by measuring the freezing point depression. Rodrigues Júnior et al. (2016) used the b-galactosidase enzyme in a concentration of $0.8 \mathrm{~g}$ per liter at a temperature of $38{ }^{\circ} \mathrm{C}$. The average hydrolysis time was $4 \mathrm{~h}$, and lactose conversion was also determined by cryoscopy until a value of $90 \%$ was reached. 
Table 1. Summary of spray drying results and powder properties

\begin{tabular}{|c|c|c|c|c|c|c|c|}
\hline Samples & F1 & F2 & F3 & $\mathbf{F 4}$ & F5 & LSD & $\mathbf{F}_{\text {calc }}$ \\
\hline $\mathrm{T}_{\text {in }}\left({ }^{\circ} \mathrm{C}\right)$ & 110 & 110 & 150 & 150 & 130 & & \\
\hline$F_{\text {atom }}(\mathrm{kg} / \mathrm{h})$ & 2.0 & 4.0 & 2.0 & 4.0 & 3.0 & - & - \\
\hline \multicolumn{8}{|c|}{ Results } \\
\hline $\mathrm{T}_{\text {out }}\left({ }^{\circ} \mathrm{C}\right)$ & $70 \pm 1$ & $70 \pm 1$ & $94 \pm 2$ & $94 \pm 2$ & $80 \pm 1$ & - & - \\
\hline $\mathrm{RH}_{\text {out }}(\%)$ & $\begin{array}{c}10.8 \pm \\
0.2\end{array}$ & $\begin{array}{c}10.8 \pm \\
0.2\end{array}$ & $\begin{array}{c}3.8 \pm \\
0.1\end{array}$ & $\begin{array}{c}3.8 \pm \\
0.1\end{array}$ & $\begin{array}{c}6.1 \pm \\
0.2\end{array}$ & - & - \\
\hline Yield (\%) & $5 \pm 2.3$ & $13 \pm 3.4$ & $18 \pm 2.8$ & $\begin{array}{c}50 \pm \\
3.1\end{array}$ & $7 \pm 1.9$ & - & - \\
\hline Moisture (\%) & $5.130^{\mathrm{a}}$ & $3.933^{\mathrm{b}}$ & $1.739^{\mathrm{c}}$ & $0.563^{\mathrm{d}}$ & $2.005^{\mathrm{c}}$ & 1.112 & $58.78^{* *}$ \\
\hline Water activity & $0.438^{\mathrm{a}}$ & $0.326^{\mathrm{c}}$ & $0.265^{\mathrm{d}}$ & $0.212^{\mathrm{e}}$ & $0.352^{\mathrm{b}}$ & 0.011 & $1199.34 * *$ \\
\hline $\begin{array}{l}\text { Hygroscopicity } \\
\qquad(\mathrm{g} / 100 \mathrm{~g})\end{array}$ & $16.0^{\mathrm{b}}$ & $17.8^{\mathrm{ab}}$ & $18.4^{\mathrm{a}}$ & $19.7^{\mathrm{a}}$ & $19.2^{\mathrm{a}}$ & 2.137 & $9.94 * *$ \\
\hline $\begin{array}{l}\text { Bulk Density } \\
\qquad\left(\mathrm{g} / \mathrm{cm}^{3}\right)\end{array}$ & $0.44^{\mathrm{a}}$ & $0.35^{b}$ & $0.33^{\mathrm{bc}}$ & $0.28^{c}$ & $0.33^{\mathrm{bc}}$ & 0.063 & $20.39 * *$ \\
\hline $\begin{array}{l}\text { Tap Density } \\
\left(\mathrm{g} / \mathrm{cm}^{3}\right)\end{array}$ & $0.63^{\mathrm{a}}$ & $0.61^{\mathrm{ab}}$ & $0.55^{\mathrm{c}}$ & $0.49^{d}$ & $0.58^{\mathrm{bc}}$ & 0.433 & $34.07 * *$ \\
\hline Hausner Ratio & 1.58 & 1.74 & 1.68 & 1.75 & 1.76 & - & - \\
\hline $\mathrm{L}$ & $85.633^{d}$ & $88.543^{b}$ & $86.593^{c}$ & $80.72^{\mathrm{e}}$ & $89.527^{a}$ & 0.647 & $609.78 * *$ \\
\hline$a^{*}$ & $0.23^{\mathrm{b}}$ & $-0.32^{b}$ & $0.11^{\mathrm{b}}$ & $3.777^{\mathrm{a}}$ & $-0.433^{b}$ & 0.329 & $495.29 * *$ \\
\hline$b^{*}$ & $11.007^{\mathrm{c}}$ & $11.363^{\mathrm{c}}$ & $15.707^{\mathrm{b}}$ & $24.59^{\mathrm{a}}$ & $11.137^{\mathrm{c}}$ & 1.302 & $436.4^{* *}$ \\
\hline
\end{tabular}

LSD - Least Significant Difference; **Significant at $1 \%$ probability. Mean values followed by the same letter are not statistically different. Tukey Test for $\mathrm{p}>0.05$ 


\subsection{Process Yield}

From table 1, process yields vary between $5.5 \%$ to $50.7 \%$, which is considered low, according to Bhandari and co-workers, that consider a minimum of $50 \%$ yield for a successful process (Bhandari et al., 1997). Comparing these values with other lactose-free spray-drying processes, Shresta and co-workers obtained $25 \%$ of the powder in the cyclone, while Torres et al. did not report values mentioning only low yields (Torres et al., 2017). Values between 20 and $60 \%$ are considered common for products with high sugar content (Dantas et al., 2018). To better understand the influence of parameters on these results, a polynomial equation was fitted to the experimental data (eq.4), and the surface response is presented in Figure 2A.

$$
\text { yield }=22.86-0.284 \times T_{\text {in }}-29.26 \times F_{\text {atom }}+0.3 \times T_{\text {in }} \times F_{\text {atom }}, \mathrm{R}^{2}=78.54
$$

Increasing inlet temperatures in combination with increasing atomization flow rate results in higher yield. The process variables imposed result in low relative humidity at the outlet as well as smaller droplets. The combination of both factors results in high drying kinetics, due to increased contact surface area between gas and droplet and vapor pressure leading to higher evaporation rates. Results suggest that higher drying kinetics leads to particles with lower water content when they strike the wall of the dryer, thus increasing yield. The glass transition temperature is used to analyze the process yield, which is a parameter that can be estimated by both sugar and water content using the Gordon-Taylor equation (Gordon \& Taylor, 1952). Generally, it is assumed that when wet-bulb temperatures and outlet temperatures are close or higher than $\mathrm{T}_{\mathrm{g}}$, the powder sticks to the drying chamber (Hennigs et al., 2001). However, if the powder particle has lower water content, its glass transition temperature will be higher, thus explaining the best yield result for sample 4 and the lower yields of the other samples. Nevertheless, even for the higher value of yield, half of the product lay within the drying chamber, and the explanation might be because the outlet temperature is much higher than the glass transition temperature. Other authors report that low values of relative humidity result in better yields for milk drying (Schuck et al., 2005).

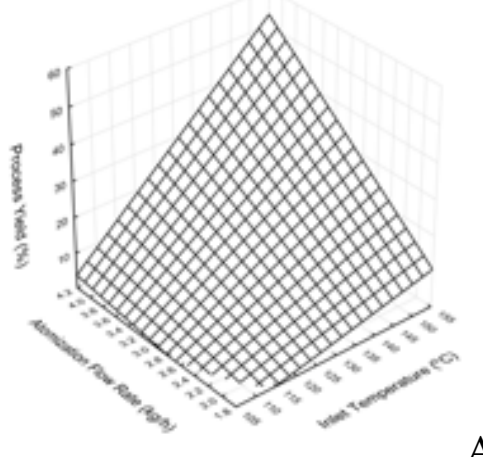

A

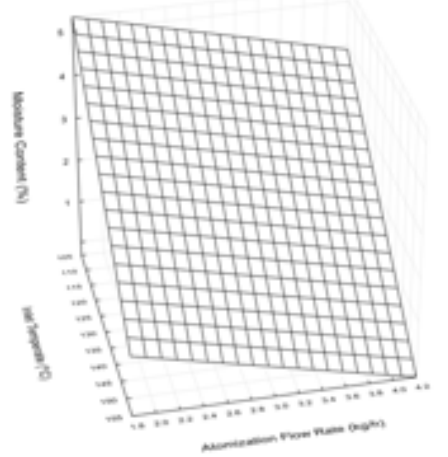

$\mathrm{B}$

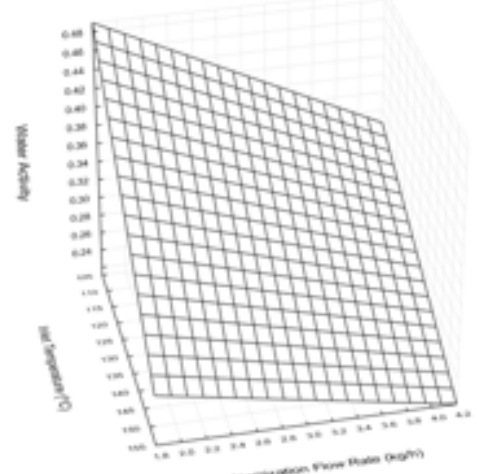

$\mathrm{C}$ 

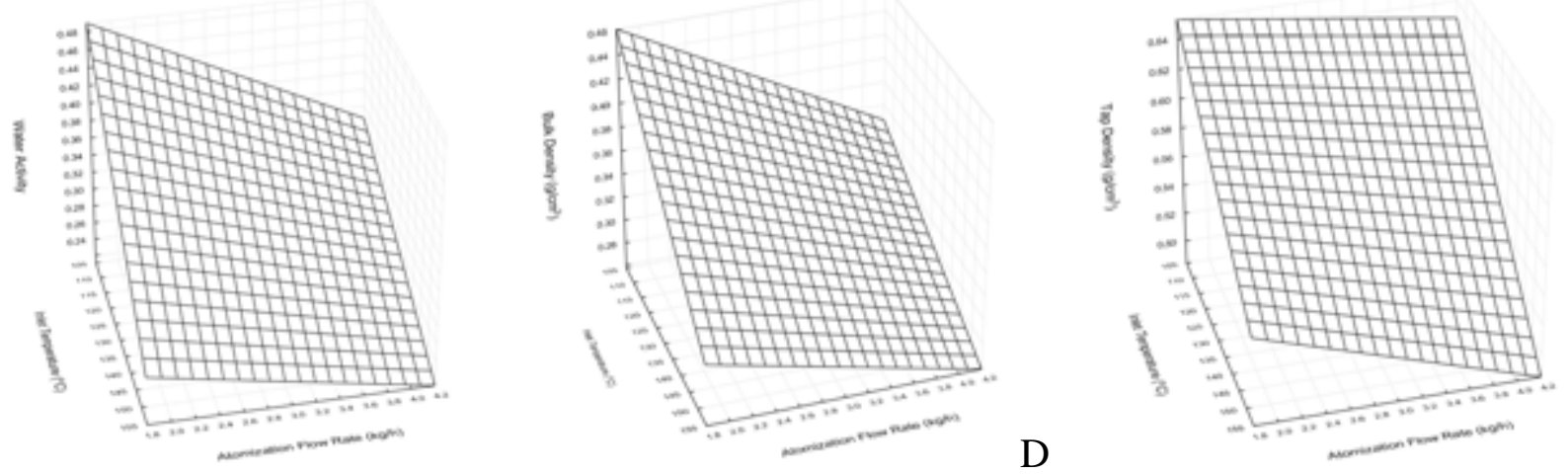

$\mathrm{C}$

Figure 2. Surface response graphs generated by the fitted polynomial equation on a) process yield; b) Moisture content; c) Water activity; d) Bulk Density; e) Tap Density; f)

Hygroscopicity

\subsection{Moisture Content}

Moisture content ranged from 0.56 to $5.13 \%$, which was below the $10 \%$ obtained by Torres et al. (Torres et al., 2017). The difference can be explained by the lower residence time of the lab-scale equipment used since temperature profiles are comparable. Except for sample 1, all other samples have moistures below the value recommended by ADMI of 4.5\%(ADMI, 1971). Analyzing Figure 2B generated by equation 5, when lactose-free milk was sprayed with a low atomization flow rate in combination with low temperatures, powdered samples had higher moisture content.

Moisture Content $=15.35-0.085 \times T_{\text {in }}-0.627 \times F_{\text {atom }}+0.0026 \times T_{\text {in }} \times F_{\text {atom }}, \mathrm{R}^{2}=91.73$ (eq.5)

This can be explained by the lower evaporation rate and higher relative humidity at the outlet. Further analysis of Figure 2B, reveals that inlet temperature has more influence on moisture content than atomization flow rate.

\subsection{Water Activity}

Water activity ranged from 0.212 to 0.438 , which is comparable and similar to the values determined by Lloyd and co-workers on the US produced whole milk powder (Lloyd et al., 2009). (Shrestha et al., 2007) report a critical water activity of 0.15 and $2.4 \mathrm{~g}$ of moisture for storage temperature of $23^{\circ} \mathrm{C}$ for three weeks. Considering water activity, the obtained values are all above the critical parameter.

$$
a_{w}=1.21-0.006 \times T_{\text {in }}-0.137 \times F_{\text {atom }}+0.00037 \times T_{\text {in }} \times F_{\text {atom }}, \mathrm{R}^{2}=90.40 \quad \text { (eq. 6) }
$$

Using equation 6, a surface response was created (Figure 2C), which shows increasing water activity with lower inlet temperatures and a lower atomization flow rate. According to (Ferreira et al., 2019) water activity follows a similarly trendo to moisture content, which can be explained by the lower evaporation rate and higher relative humidity at the outlet. 


\subsection{Bulk and Tap Density}

From Table 1, bulk density values range from 0.4 to $0.27 \mathrm{~g} / \mathrm{cm}^{3}$, while tap density 0.63 to $0.49 \mathrm{~g} / \mathrm{cm}^{3}$. Both values are in the range of other works on milk powder with lactose and without lactose (Aguilar \& Ziegler, 1994; Kelly et al., 2002). The equation was used to model the experimental data, and the results are shown in Figure 2D and 2E, along with equations 7 and 8 .

$$
\begin{gathered}
\text { Bulk Density }=0.96-0.004 \times T_{\text {in }}-0.1 \times F_{\text {atom }}+0.00051 \times T_{\text {in }} \times F_{\text {atom }}, \mathrm{R}^{2}=96.32 \text { (eq.7) } \\
\text { Tap Density }=0.84-0.001 \times T_{\text {in }}+0.02 \times F_{\text {atom }}-0.0003 \times T_{\text {in }} \times F_{\text {atom }}, \mathrm{R}^{2}=97.88 \text { (eq.8) }
\end{gathered}
$$

The results show that lower temperatures result in products with higher bulk and tap density, while similar behavior is identified with lower atomization values, which also result in denser products. It was also found that the outlet temperature has more influence than the atomization flow rate on this property. Consequently, relative humidity has more influence than the particle size. Some explanations can be discussed to understand this result. Firstly, powders with higher residual moisture are denser simply because particles are heavier than powders with lower residual moisture, since water has a higher density than the bulk powder. Secondly, if higher temperatures are used, then the rate of evaporation will be higher, and the droplet upon dehydration rapidly forms a thicker outer layer, which is maintained throughout the drying process by internal pressure caused by evaporation of liquid. The result is a balloon-shaped particle with high volume and low density. However, if the evaporation rate is low, the droplets dehydrate more slowly, and the outer layer will accommodate the loss of liquid inside the droplet. Therefore, the formation of a wrinkled particle occurs, with smaller volume and consequently, greater density(Vicente et al., 2013). Air inclusion can also serve as justification for lower density, as droplets drying rapidity will have higher viscosity at the outer layer, entrapping more air than the droplets with lower viscosity at the outer layer.

Hausner's Ratio can be used as an indication of powder flowability in which values are above 1.25 powders are generally considered to be poorly flowable or cohesive. For lactose-free milk powders, all values are above 1.25; therefore all are considered as poorly flowable or cohesive. Similar results were obtained by Crowley et al., measuring the flow properties with a powder flow tester on concentrated milk protein powders. Powders with lactose content below 6.4\% revealed to be cohesive (Crowley et al., 2014).

\subsection{Color}

Color is an important characteristic because it is related to the sensorial attractiveness of the product (Fernández-Vázquez et al., 2017). All samples presented an off-white to yellow color. To determine this property accurately, color measurements were performed using the $\mathrm{L}^{*} \mathrm{a} * \mathrm{~b}$ color space. Parameter L represents the sample brightness and ranges from 0 for darker samples to 100 for lighter samples. Parameter a * represents the green-red axis, with negative values for green up to -120 , and positive values for red up to 120 . The parameter $b *$ represents the blue-yellow axis, with negative values for blue up to -120 and positive values for yellow up to 120. According to table 1, the values obtained for parameter $\mathrm{L}$ varied between 80 and 89 , for the parameter a $*$, between -0.43 and 3.7 , and for parameter $\mathrm{b} *$ 
ranged from 11.0 to 24.59 . Koc et al, reported similar mean values for whole milk powder produced by spray drying, with $\mathrm{L}^{*}=79.1 \pm 1.6$, a* $=0.9 \pm 0.9$ e $\mathrm{b}^{*}=7.7 \pm 1.2$ (Koc et al., 2003). Equation 3 was fitted to all parameters, however the determination coefficient for parameter L was too low.

$$
\begin{gathered}
a=12.1-0.11 \times T_{\text {in }}-6.07 \times F_{\text {atom }}+0.05 \times T_{\text {in }} \times F_{\text {atom }}, \mathrm{R}^{2}=77.05 \\
b=19.23-0.096 \times T_{\text {in }}-11.54 \times F_{\text {atom }}+0.106 \times T_{\text {in }} \times F_{\text {atom }}, \mathrm{R}^{2}=77.37
\end{gathered}
$$

Process variables had small effects on color, except for sample 3 and $4\left(\mathrm{~T}_{\text {in }}=150^{\circ} \mathrm{C}, \mathrm{F}_{\text {atom }}=2\right.$ and $4 \mathrm{~kg} / \mathrm{h}$ ). This sample presented the highest $\mathrm{a}^{*}$ and $\mathrm{b}^{*}$ values along with the lowest value for L. This combination confirms the yellow to brown coloration of this sample. Since samples 3 and 4 had the highest outlet temperature, it is assumed that these samples had a higher percentage of sugar molecules above the amorphous state, yielding lower viscosity (Lievonen et al., 1998). A possible explanation might be the extensive glucose and galactose crystallization increasing the rate of Maillard reactions due to higher molecular mobility. This higher molecular mobility can reduce the activation energy required for the reaction between the monosaccharides and casein(Naranjo et al., 2013). Maillard reactions are responsible for the appearance of the color brown and increases in $b^{*}$ values (Leiva et al., 2017). Moreover, other works suggest that sugar crystallization can also initiate lipid oxidation and thus alteration on food color (Thomsen et al., 2005).

\subsection{Particle Morphology}

SEM micrographs of the spray-dried lactose-free milk powders are shown in Figure 3. In all samples, the powders existed more as agglomerates of small particles rather than a single discrete particle. The agglomeration seemed to be more compact and tightly bound with increasing inlet temperature and atomization flow rate. Agglomeration has been reported to be partly related to the presence of a high level of surface free fat or proteins and is generally attributed to water bridges between particles. While droplets are drying, water inside diffuses to the outer layer while other molecules diffuse in the opposite direction. Since fat globules and proteins are larger molecules with transport velocities lower than glucose and galactose, it is expected that a higher concentration of these molecules can be found at the particle crust (Kim et al., 2009). This is especially true for lower evaporation rates. However, when drying rates are higher and molecular transport velocities are slower, it is expected more uniform distribution of components due to particle quenching. In all samples, no pores or cracks were detected, and the internal structures revealed the presence of large-sized vacuoles, which is a common feature typically observed in spray-dried powders (Nuzzo et al., 2017). No noticeable smooth surfaces were identified. 

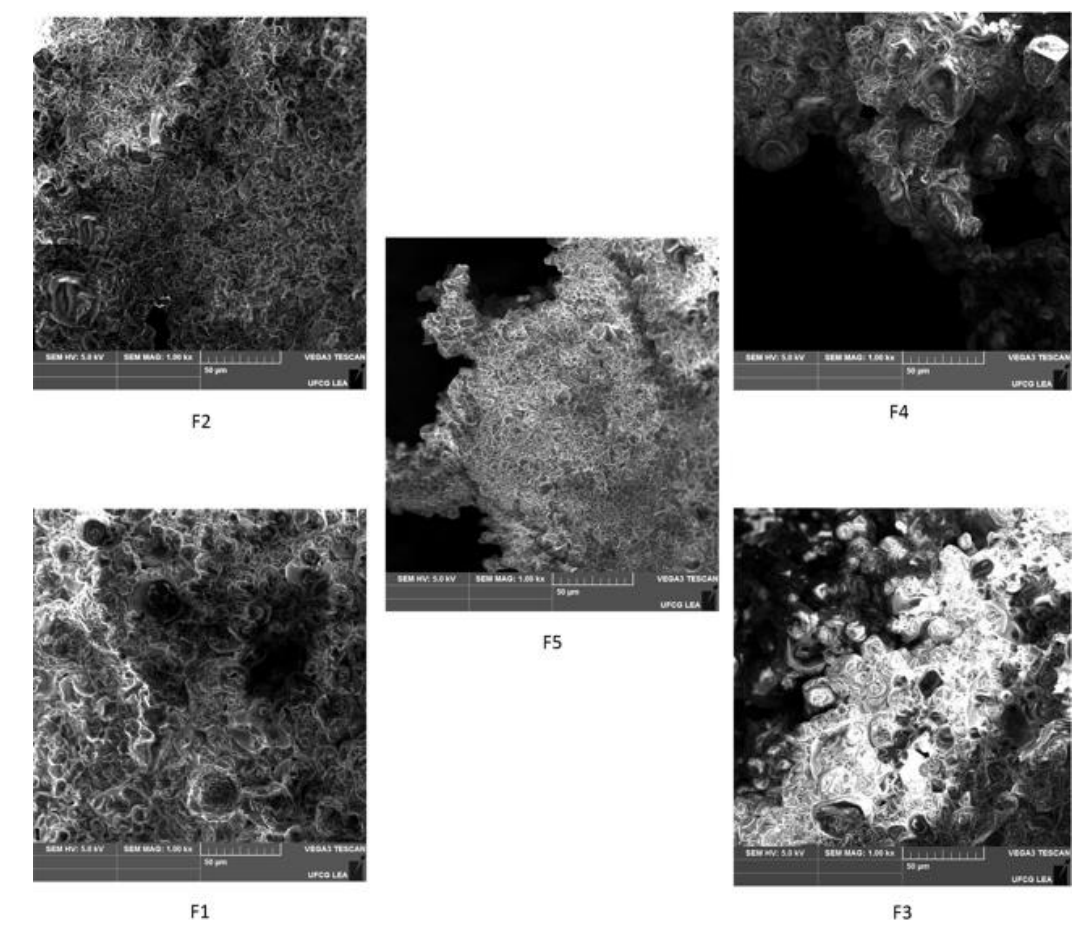

F1

F3

Figure 3. Micrographs of lactose-free powder milk at a magnification of 1000x

\subsection{Particle Size Distribution}

A two-fluid nozzle was used where the atomization gas disrupts the liquid cohesive forces into droplets (Lisboa et al., 2018). The atomization process is heterogeneous with, different mechanisms of separation and union of droplets yielding different sizes. Therefore, spray nozzles do not produce uniform sprays, with droplets of identical size in any condition of use(Rocha et al., 2018). Considering this, results are expressed in the form of $D_{n} 10, D_{n} 50$, and $D_{n} 90$, which means, for example, $D_{n} 50$, half of the particle measurements $(50 \%)$ are below the given value, while the other half is above. From table $2, D_{n} 50$ values ranged from 5.6 to $13.5 \mu \mathrm{m}$, with higher values of particle size obtained for the samples with lower atomization flow rate (F1 and F3) and smaller values for higher atomization flow rate (F2 and F4). Sample F3 presented an intermediate particle size as a result of an intermediate atomization flow rate. These values are within the range of particle sizes obtained by (Nuzzo et al., 2017), while spray drying whole milk using two-fluid nozzles in 3 different spray dryer scales (Nuzzo et al., 2017). In addition to the flow rate, a small increase can be identified when comparing samples with different inlet temperatures and lower $F_{\text {atom. This }}$ can be explained by the ballooning effect previously discussed. 
Table 2. Particle size distribution for lactose-free powder milk

\begin{tabular}{cccccc}
\hline Samples & F1 & F2 & F3 & F4 & F5 \\
\hline $\mathrm{D}_{\mathrm{n} 10}(\mu \mathrm{m})$ & 4.1 & 3.1 & 5.6 & 3.0 & 3.4 \\
$\mathrm{D}_{\mathrm{n}} 50(\mu \mathrm{m})$ & 7.8 & 5.6 & 13.5 & 6.0 & 7.9 \\
$\mathrm{D}_{\mathrm{n} 90}(\mu \mathrm{m})$ & 23.2 & 10.9 & 31.3 & 12.6 & 11.9 \\
Span & 2.44 & 1.39 & 1.90 & 1.59 & 1.08 \\
\hline
\end{tabular}

\subsection{Powders Chemical Characterization}

Three chemical parameters, $\mathrm{pH}$, titratable acidity, and protein content, were evaluated for each powder sample, and results were summarized in Table 3. $\mathrm{pH}$ and temperature are two important factors on protein denaturation and consequent agglomeration (Dissanayake et al., 2013). $\mathrm{pH}$ values were obtained by the reconstitution of powder milk with distilled water. Values varied between 6.478 to 6.71 , while the feed material was 6.711. Comparing with the initial $\mathrm{pH}$ values of hydrolyzed milk, small changes are verified, and no trends are identified. Titratable acidity (TA) of milk has been used as an indicator of quality since alterations in TA can be associated with milk contamination ( $\mathrm{Lu}$ et al., 2013). Moreover, during the spray drying process, TA is extremely important due to the relation that TA and drying temperatures can induce milk properties. TA values of feed material if 18.36 , while for powdered samples, the values ranged between 13.58 to 19.36 . Comparison and analysis reveal that powders produced with lower inlet temperatures resulted in lower values of TA. A decrease in TA is an indicator of lower nutritional properties of milk. This is because interactions between proteins present in the milk, such as casein, are impaired by lower values of TA (Kethireddipalli et al., 2010). The instability in casein mediated alterations resulting in a decrease of calcium and phosphorus bioavailability (Tzannis \& Prestrelski, 1999). The instability of proteins is also involved in particle morphology during the spray drying process. Here, our results showed that increasing inlet temperature results in an increase of TA. In terms of protein content, it is known that higher temperatures can induce destabilization of soluble proteins(Liang et al., 2017). Our results demonstrated a decrease in protein content in the milk powder with a higher inlet temperature. Thus, the consequence of temperature is a decrease in the nutritional quality of the product. In the milk powder, alterations in protein content impair the solubility of the product. Moreover, during drying process, the higher temperatures can mediate protein denaturation and protein-protein interaction (Singh \& Creamer, 1991). These alterations in protein characteristics are also involved in the particle morphology and composition. Therefore, the agglomeration observed in particles obtained with increasing inlet temperature and atomization flow rate can be related to alterations in protein structure in the powdered (Millqvist-Fureby et al., 2001). 
Table 3. Summary of milk and powders chemical characterization

\begin{tabular}{|c|c|c|c|c|c|c|c|c|c|}
\hline & $\begin{array}{c}\text { In } \\
\text { natura }\end{array}$ & Hydrolyzed & F1 & F2 & F3 & F4 & F5 & LSD & $\mathbf{F}_{\text {calc }}$ \\
\hline $\mathrm{pH}$ & $\begin{array}{c}6.874 \\
\pm 0.016\end{array}$ & $\begin{array}{c}6.711 \pm \\
0.010\end{array}$ & $6.535^{\mathrm{b}}$ & $6.710^{\mathrm{a}}$ & $6.676^{\mathrm{a}}$ & $6.478^{\mathrm{b}}$ & $6.693^{\mathrm{a}}$ & 0.115 & $16.98 * *$ \\
\hline TA & $\begin{array}{l}19.333 \\
\pm 0.577\end{array}$ & $\begin{array}{c}18.376 \pm \\
0.678\end{array}$ & $13.58^{\mathrm{c}}$ & $14.76^{\mathrm{c}}$ & $16.32^{\mathrm{b}}$ & $19.36^{\mathrm{a}}$ & $14.28^{c}$ & 71.38 & $71.38 * *$ \\
\hline $\begin{array}{c}\text { Protein } \\
(\%)\end{array}$ & 3.075 & 3.075 & $31.93^{b}$ & $21.90^{c}$ & $16.87^{d}$ & $20.63^{d}$ & $32.40^{\mathrm{a}}$ & 0.269 & $14794 * *$ \\
\hline
\end{tabular}

LSD - Least Significant Difference; **Significant at 1\% probability. Mean values followed by the same letter are not statistically different. Tukey Test for $\mathrm{p}>0.05$

\section{Conclusions}

Lactose-free milk was successfully dehydrated using various spray drying kinetics by a combination of inlet temperatures with atomization flow rate. Inlet temperature was the most influential parameter, with higher values leading the process to higher yields and powders to lower moisture, lower density, and lower protein retention. As for the atomization flow rate, increases also lead to powders with lower moistures and lower densities but no influence on chemical properties. By a combination of both parameters, it is concluded that drying kinetics plays an important role in powder properties. Powder morphology presented spherical particles with large vacuoles and agglomerated, possibly due to protein denaturation at the surface.

\section{References}

ADMI, C. (1971). Standards for Grades of Dry Milk including Methods of Analysis. Bulletin, 916.

Aguilar, C. A., \& Ziegler, G. R. (1994). Physical and microscopic characterization of dry whole milk with altered lactose content. 1. Effect of lactose concentration. Journal of Dairy Science, 77(5), 1189-1197. https://doi.org/10.3168/jds.S0022-0302(94)77057-0

Ahmad, I., \& Nguyen, L. T. (2017). Water-Glass Transition Temperature Profile During Spray Drying of Sugar-Rich Foods. Glass Transition and Phase Transitions in Food and Biological Materials, 239. https://doi.org/10.1002/9781118935682.ch10

Anonyme, A. O. A. C. (1990). Official methods of analysis (14 ed.): Association of Official Analytical Chemist. 
Bhandari, B. R., Datta, N., \& Howes, T. (1997). Problems associated with spray drying of sugar-rich foods. Drying Technology, 15(2), 671-684.

https://doi.org/10.1080/07373939708917253

Cheng, H., Ru-Gang, Z., Erichsen, H., Soerensen, J., Petersen, M. A., \& Skibsted, L. H. (2017). High temperature storage of infant formula milk powder for prediction of storage stability at ambient conditions. International Dairy Journal.

https://doi.org/10.1016/j.idairyj.2017.05.007

Crowley, S. V., Gazi, I., Kelly, A. L., Huppertz, T., \& O’Mahony, J. A. (2014). Influence of protein concentration on the physical characteristics and flow properties of milk protein concentrate powders. Journal of Food Engineering, 135, 31-38.

https://doi.org/10.1016/j.jfoodeng.2014.03.005

Dantas, D., Pasquali, M. A., Cavalcanti-Mata, M., Duarte, M. E., \& Lisboa, H. M. (2018). Influence of Spray Drying Conditions on the Properties of Avocado Powder Drink. Food Chemistry, 266, 284-291. https://doi.org/10.1016/j.foodchem.2018.06.016

Dissanayake, M., Ramchandran, L., Piyadasa, C., \& Vasiljevic, T. (2013). Influence of heat and $\mathrm{pH}$ on structure and conformation of whey proteins. International Dairy Journal, 28(2), 56-61. https://doi.org/10.1016/j.idairyj.2012.08.014

Fernández-Vázquez, R., Stinco, C. M., Hernanz Vila, D., Heredia, F. J., Chaya, C., \& Vicario, I. M. (2017). Internal preference mapping of milk-fruit beverages: Influence of color and appearance on its acceptability. Food Science \& Nutrition. https://doi.org/10.1002/fsn3.494

Ferreira, S., Araujo, T., Souza, N., Rodrigues, L., Lisboa, H. M., Pasquali, M., ... Rocha, A. P. (2019). Physicochemical, morphological and antioxidant properties of spray-dried mango kernel starch. Journal of Agriculture and Food Research, 100012. https://doi.org/10.1016/j.jafr.2019.100012

Fialho, T. L., Martins, E., Silveira, A. C. P., Silva, C. R. d. J., Perrone, Í. T., Schuck, P., \& de Carvalho, A. F. (2017). Lactose hydrolyzed milk powder: Thermodynamic characterization of the drying process. Drying Technology, 1-10. https://doi.org/10.1080/07373937.2017.1365725

Geiger, B., Nguyen, H. M., Wenig, S., Nguyen, H. A., Lorenz, C., Kittl, R., ... Nguyen, T. H. (2016). From by-product to valuable components: Efficient enzymatic conversion of lactose in whey using $\beta$-galactosidase from Streptococcus thermophilus. Biochemical engineering journal, 116, 45-53. https://doi.org/10.1016/j.bej.2016.04.003

Gordon, M., \& Taylor, J. S. (1952). Ideal copolymers and the second-order transitions of synthetic rubbers. I. Non-crystalline copolymers. Journal of Chemical Technology and Biotechnology, 2(9), 493-500. https://doi.org/10.1002/jctb.5010020901

Hennigs, C., Kockel, T., \& Langrish, T. (2001). New measurements of the sticky behavior of skim milk powder. Drying Technology, 19(3-4), 471-484.

https://doi.org/10.1081/DRT-100103929 


\section{Macrothink}

Hertzler, S., Savaiano, D. A., Dilk, A., Jackson, K. A., Bhriain, S. N., \& Suarez, F. L. (2017). Nutrient Considerations in Lactose Intolerance. In Nutrition in the Prevention and Treatment of Disease (Fourth Edition) (pp. 875-892): Elsevier.

https://doi.org/10.1016/B978-0-12-802928-2.00040-0

Jansson, T., Clausen, M. R., Sundekilde, U. K., Eggers, N., Nyegaard, S., Larsen, L. B., ... Bertram, H. C. (2014). Lactose-hydrolyzed milk is more prone to chemical changes during storage than conventional ultra-high-temperature (UHT) milk. Journal of agricultural and food chemistry, 62(31), 7886-7896. https://doi.org/10.1021/jf501671z

Júnior, P. H. R., de Sá Oliveira, K., de Almeida, C. E. R., De Oliveira, L. F. C., Stephani, R., da Silva Pinto, M., ... Perrone, Í. T. (2016). FT-Raman and chemometric tools for rapid determination of quality parameters in milk powder: Classification of samples for the presence of lactose and fraud detection by addition of maltodextrin. Food Chemistry, 196, 584-588. https://doi.org/10.1016/j.foodchem.2015.09.055

Kelly, J., Kelly, P. M., \& Harrington, D. (2002). Influence of processing variables on the physicochemical properties of spray dried fat-based milk powders. Le Lait, 82(4), 401-412. https://doi.org/10.1051/lait:2002019

Kethireddipalli, P., Hill, A. R., \& Dalgleish, D. G. (2010). Protein interactions in heat-treated milk and effect on rennet coagulation. International Dairy Journal, 20(12), 838-843. https://doi.org/10.1016/j.idairyj.2010.06.003

Kim, E. H. J., Chen, X. D., \& Pearce, D. (2009). Surface composition of industrial spray-dried milk powders. 1. Development of surface composition during manufacture. Journal of Food Engineering, 94(2), 163-168. https://doi.org/10.1016/j.jfoodeng.2008.09.021

Koc, A., Heinemann, P., \& Ziegler, G. (2003). A Process for Increasing the Free Fat Content of Spray-dried Whole Milk Powder. Journal of Food Science, 68(1), 210-216. https://doi.org/10.1111/j.1365-2621.2003.tb14141.x

Leiva, G. E., Naranjo, G. B., \& Malec, L. S. (2017). A study of different indicators of Maillard reaction with whey proteins and different carbohydrates under adverse storage conditions. Food Chemistry, 215, 410-416. https://doi.org/10.1016/j.foodchem.2016.08.003

Liang, Y., Matia Merino, L., Gillies, G., Patel, H., Ye, A., \& Golding, M. (2017). The Heat Stability of Milk Protein-stabilized Oil-in-water Emulsions: A Review. Current Opinion in Colloid \& Interface Science. https://doi.org/10.1016/j.cocis.2017.03.007

Lievonen, S. M., Laaksonen, T. J., \& Roos, Y. H. (1998). Glass transition and reaction rates: Nonenzymatic browning in glassy and liquid systems. Journal of agricultural and food chemistry, 46(7), 2778-2784. https://doi.org/10.1021/jf980064h

Lineweaver, H., \& Burk, D. (1934). The determination of enzyme dissociation constants. Journal of the American Chemical Society, 56(3), 658-666. https://doi.org/10.1021/ja01318a036 
Lisboa, H. M., Duarte, M. E., \& Cavalcanti-Mata, M. E. (2018). Modeling of food drying processes in industrial spray dryers. Food and bioproducts processing, 107, 49-60. https://doi.org/10.1016/j.fbp.2017.09.006

Lloyd, M., Drake, M., \& Gerard, P. (2009). Flavor Variability and Flavor Stability of US-Produced Whole Milk Powder. Journal of Food Science, 74(7). https://doi.org/10.1111/j.1750-3841.2009.01299.x

Lu, M., Shiau, Y., Wong, J., Lin, R., Kravis, H., Blackmon, T., ... Chang, J. (2013). Milk spoilage: Methods and practices of detecting milk quality. Food and Nutrition Sciences, 4(7), 113. https://doi.org/10.4236/fns.2013.47A014

McCleary, B. V., \& Charnock, S. (2010). Assay for determination of free D-galactose and/or L-arabinose. In: Google Patents.

Milkovska-Stamenova, S., \& Hoffmann, R. (2017). Influence of storage and heating on protein glycation levels of processed lactose-free and regular bovine milk products. Food Chemistry, 221, 489-495. https://doi.org/10.1016/j.foodchem.2016.10.092

Millqvist-Fureby, A., Elofsson, U., \& Bergenståhl, B. (2001). Surface composition of spray-dried milk protein-stabilised emulsions in relation to pre-heat treatment of proteins. Colloids and Surfaces B: Biointerfaces, $21(1), \quad 47-58$. https://doi.org/10.1016/S0927-7765(01)00183-7

Monti, L., Negri, S., Meucci, A., Stroppa, A., Galli, A., \& Contarini, G. (2017). Lactose, galactose and glucose determination in naturally "lactose free" hard cheese: HPAEC-PAD method validation. Food Chemistry, 220, 18-24.

https://doi.org/10.1016/j.foodchem.2016.09.185

Moreira, T. C., da Silva, A. T., Fagundes, C., Ferreira, S. M. R., Cândido, L. M. B., Passos, M., \& Krüger, C. C. H. (2017). Elaboration of yogurt with reduced level of lactose added of carob (Ceratonia siliqua L.). LWT-Food Science and Technology, 76, 326-329. https://doi.org/10.1016/j.lwt.2016.08.033

Morlock, G. E., Morlock, L. P., \& Lemo, C. (2014). Streamlined analysis of lactose-free dairy products. Journal of Chromatography A, 1324, 215-223.

https://doi.org/10.1016/j.chroma.2013.11.038

Munir, M., Wilson, I., Yu, W., \& Young, B. (2017). An Evaluation of Hyperspectral Imaging for Characterising Milk Powders. Journal of Food Engineering. https://doi.org/10.1016/j.jfoodeng.2017.10.001

Naranjo, G. B., Gonzales, A. S. P., Leiva, G. E., \& Malec, L. S. (2013). The kinetics of Maillard reaction in lactose-hydrolysed milk powder and related systems containing carbohydrate mixtures. Food Chemistry, 141(4), 3790-3795.

https://doi.org/10.1016/j.foodchem.2013.06.093

Nascimento, A., Cavalcanti-Mata, M. E., Martins Duarte, M. E., Pasquali, M., \& Lisboa, H. M. (2019). Construction of a design space for goat milk powder production using moisture 
sorption isotherms. Journal of Food Process Engineering, e13228.

https://doi.org/10.1111/jfpe.13228

Nijpels, H., Evers, P., Novak, G., \& Ramet, J. (1980). Application of cryoscopy for the measurement of enzymatic hydrolysis of lactose. Journal of Food Science, 45(6), 1684-1687. https://doi.org/10.1111/j.1365-2621.1980.tb07589.x

Nuzzo, M., Overgaard, J. S., Bergenståhl, B., \& Millqvist-Fureby, A. (2017). The morphology and internal composition of dried particles from whole milk-From single droplet to full scale drying. Food Structure. https://doi.org/10.1016/j.foostr.2017.02.001

Ozmen, L., \& Langrish, T. (2002). Comparison of glass transition temperature and sticky point temperature for skim milk powder. Drying Technology, 20(6), 1177-1192. https://doi.org/10.1081/DRT-120004046

Rocha, A. P. T., Lisboa, H. M., Alsina, O. L. S., \& Silva, O. S. (2018). Coating process of Phyllanthus niruri Linn granules using spouted bed. Powder Technology, 336, 85-91. https://doi.org/10.1016/j.powtec.2018.05.052

Roos, Y. H., \& Drusch, S. (2015). Phase transitions in foods: Academic Press.

Schuck, P., Mejean, S., Dolivet, A., \& Jeantet, R. (2005). Thermohygrometric sensor: A tool for optimizing the spray drying process. Innovative Food Science \& Emerging Technologies, 6(1), 45-50. https://doi.org/10.1016/j.ifset.2004.10.001

Shishir, M. R. I., \& Chen, W. (2017). Trends of spray drying: A critical review on drying of fruit and vegetable juices. Trends in Food Science \& Technology.

https://doi.org/10.1016/j.tifs.2017.05.006

Shrestha, A. K., Howes, T., Adhikari, B. P., \& Bhandari, B. R. (2007). Water sorption and glass transition properties of spray dried lactose hydrolysed skim milk powder. LWT-Food Science and Technology, 40(9), 1593-1600. https://doi.org/10.1016/j.lwt.2006.11.003

Singh, H., \& Creamer, L. K. (1991). Denaturation, aggregation and heat stability of milk protein during the manufacture of skim milk powder. Journal of Dairy Research, 58(3), 269-283. https://doi.org/10.1017/S002202990002985X

Thomsen, M. K., Lauridsen, L., Skibsted, L. H., \& Risbo, J. (2005). Two types of radicals in whole milk powder. Effect of lactose crystallization, lipid oxidation, and browning reactions. Journal of agricultural and food chemistry, 53(5), 1805-1811.

https://doi.org/10.1021/jf0485483

Tonon, R. V., Brabet, C., \& Hubinger, M. D. (2008). Influence of process conditions on the physicochemical properties of açai (Euterpe oleraceae Mart.) powder produced by spray drying. Journal of Food Engineering, 88(3), 411-418.

https://doi.org/10.1016/j.jfoodeng.2008.02.029

Torres, J. K. F., Stephani, R., Tavares, G. M., De Carvalho, A. F., Costa, R. G. B., de Almeida, C. E. R., ... Perrone, I. T. (2017). Technological aspects of lactose-hydrolyzed milk 
powder. Food Research International, 101, 45-53.

https://doi.org/10.1016/j.foodres.2017.08.043

Tzannis, S. T., \& Prestrelski, S. J. (1999). Moisture effects on protein-excipient interactions in spray-dried powders. Nature of destabilizing effects of sucrose. Journal of pharmaceutical sciences, 88(3), 360-370. https://doi.org/10.1021/js9800127

Vicente, J., Pinto, J., Menezes, J., \& Gaspar, F. (2013). Fundamental analysis of particle formation in spray drying. Powder Technology, 247, 1-7.

https://doi.org/10.1016/j.powtec.2013.06.038

\section{Copyright Disclaimer}

Copyright for this article is retained by the author(s), with first publication rights granted to the journal.

This is an open-access article distributed under the terms and conditions of the Creative Commons Attribution license (http://creativecommons.org/licenses/by/4.0/). 